\title{
CONFERENCE OPENING ADDRESS
}

\section{CPDWL Section of IFLA satellite conference: $10^{\text {th }}-13^{\text {th }}$ August 2005, Oslo, Norway.}

\author{
Ann Ritchie \\ Chair \\ Continuing Professional Development and Workplace Learning Section
}

Welcome to the Sixth World Conference on Continuing Professional Development and Workplace Learning for the Library and Information Professions. The theme of our conference which we will explore for the next two and a half days is: Continuing Professional Development - Preparing For New Roles In Libraries: A Voyage Of Discovery. And we hope it will be a 'voyage of discovery' for all the conference participants, including those who will be contributing their presentations.

My name is Ann Ritchie and I am the Chair of this IFLA Section. We are delighted to welcome you all here to the Oslo University College, and wish to thank our partners in this conference - the Faculty of Journalism, Library and Information Science. We also wish to thank our sponsors for their generous support.

\section{Background}

It was twenty years ago that the first World Conference on Continuing Education for the Library and Information Science Professions was held in August 1985, before the Chicago meeting of IFLA. And twenty years on, we are holding the sixth conference of this type and the first since we have achieved Section status in IFLA in 2002 and became the Continuing Professional Development and Workplace Learning Section.

This year, the conference Call for Papers attracted more than eighty abstracts from all parts of the world, and the final selections for presentations which we will be hearing over the next couple of days, represent contributions from all types of libraries and demonstrate an extremely high quality of scholarship.

In our voyage of discovery, we will be exploring the theme of 'new roles in libraries' and how our presenters have charted the waters and prepared themselves and their colleagues for these new roles, through their professional development and learning activities and programs.

We will hear about examples of new roles on the high seas of the broader information industry, and about how the profession is reinventing itself to adapt to changing environmental conditions, increased demands and expectations of clients and stakeholders, and much about the influences of technology. We will hear about competency frameworks which can help us to 'futureproof' ourselves, to make sense of the changes and to prepare ourselves to ensure we have the skills which give us a place in the world. We will be challenged to learn from others' research and their experiences, and contemplate how we can apply this evidence to our own situations. And we will have opportunities to talk to our colleagues about the issues that have been raised and the solutions offered.

And finally, I hope we will be challenged to take home what we learn and apply it to our professional practice. In this way, we are the role models for our colleagues whom we encourage to be part of a continuous improvement process. 


\section{The voyage from CPERT to CPDWL}

Before we commence the presentations I would like to set the scene with a few introductory remarks about the evolution of the Section, and the reasons that the name was changed from the Continuing Professional Education Round Table (CPERT) to the Continuing Professional Development and Workplace Learning Section. In particular, I would like to highlight the inclusion of the concept of workplace learning.

The change of name signified a broader scope and placed an emphasis on a number of distinguishing characteristics which deserve some reflection.

Firstly, it broadened the concept of continuing professional education to that of continuing professional development, taking in all aspects of a professional's role, and recognising that education is only one of the ways in which individuals continue to learn, grow and develop as professionals throughout their working careers and their professional lives.

Secondly, the addition of the concept 'workplace learning' signified the inclusion of all the different types of developmental activities associated with the workplace - both the formal staff development and training programs of our workplaces, and the less formalised learning opportunities which occur within our normal working lives. Examples of these include work-based mentoring and coaching, and the focused learning that occurs in discrete projects and work experience placements.

Thirdly, the alignment of continuing professional development with workplace learning suggests that workplace learning activities have an important contribution to make towards continuously improving the quality of our workforce and raising standards of professional practice. So the more we can recognise workplace learning as valid and useful, and the more we can incorporate it into our planning as a training and professional development strategy, the more value we will get from it.

And fourthly, I believe it is worth thinking about the fact that as a profession, librarianship is only in the early stages of implementing structures and processes for continuous quality improvement in professional practice. Professional associations have a leading role to play here, because they are the bodies charged with responsibility for maintaining standards for education, as well as professional practice. Some of the papers we will hear in this conference will elaborate on these latter themes about quality improvement and the role of professional associations in setting and maintaining standards of education and professional practice; and a number will develop themes about the value and function of workplace learning activities in building an integrated competency framework.

\section{The importance of workplace learning}

In recent times there has been some research done into the value of workplace learning. Jana Varlejs (1997) reported on the findings of a survey of members of the American Library Association, noting that librarians in the survey spent three times as many hours on selfdirected workplace learning than in formal continuing education. ${ }^{1}$

The March 2004 issue of the International Journal of Training and Development is devoted to the theme of workplace learning, and Senker \& $\mathrm{Hyman}^{2}$ in their editorial, noted that research in Holland showed that there is a considerable amount of learning occurring in the workplace. They provided the example of the success of the Japanese engineering industry between the 1950s and 1990s, stating that this was probably due 'more to companies' ensuring that their engineers and other employees received balanced experience in work, rather than to the quality of Japanese education or formal training'.

In their book entitled Life, Work and Learning: Practice in Postmodernity, Beckett and Hager $^{3}$ explored the concept and practice of workplace learning. They outlined six main 
features of practice-based, workplace learning, which they characterised as being organic/holistic; contextual; activity- and experience-based; arising in situations where learning is not the main aim; activated by individual learners rather than by teachers/trainers; and often collaborative/collegial. They illustrated these features of practice-based learning by exploring workplace case studies of mentoring, project work, and integrated competencies. These are all activities which can occur on our everyday workplaces.

One of the main themes of the book is that professional judgement is learned best in context, and therefore, the workplace has advantages for professional development over a traditional 'front end' model of education which occurs in educational institutions and doesn't provide the same opportunities for integrating theory and practice. We intend that the Section will focus more on workplace learning and will incorporate more workplace learning research and practice into its program.

\title{
The way forward
}

As with any voyage, it is important to have a destination, and more pragmatically, a way of getting there. For the Section, we have a broader scope - professional development in all its aspects and workplace learning with all its challenges.

At this conference, we are on a voyage of discovery. For the next few days we will sail in the same ship, expertly guided by our presenters in the exploration of new and emerging roles in libraries and about how we can prepare for these through our continuing professional development and workplace learning activities.

For participants in this conference, and for our colleagues in all types of libraries librarians, library technicians, library assistants and others who have a vested interest in the 'library of the future', the proceedings of this conference propose that there are ways by which we can actively create our own future.

I am very pleased to launch the metaphorical 'good ship CPDWL' and wish all on board an inspiring voyage to our destination - a conference which will add to our own professional development and will contribute to the future knowledge base of the Section and the profession.

\author{
References \\ ${ }^{1}$ Varlejs, J. Facilitating workplace learning. In: Layzell Ward, P. \& Weingand, D. E. (eds.) \\ Human Development: Competencies for the Twenty-First Century: Papers from the IFLA \\ CPERT Third International Conference on Continuing Professional Education for the Library \\ and Information Professions, Munchen: K.G. Saur, 1997: pp98-104. \\ ${ }^{2}$ Senker, P. \& Hyman, J. (2004). Editorial. International Journal of Training and \\ Development 2004, 8 (1), 3-7. \\ ${ }^{3}$ Beckett, D. \& Hager, P. Life, Work and Learning: Practice in Postmodernity. London: \\ Routledge, 2002.
}

